European journal of American studies

\title{
Will You Awaken When Your Netflix No Longer Works? American Films, Television Productions and Social Transformations in Poland
}

\section{Mirosław Filiciak}

\section{OpenEdition}

\section{Journals}

Electronic version

URL: https://journals.openedition.org/ejas/13568

DOI: $10.4000 /$ ejas. 13568

ISSN: 1991-9336

Publisher

European Association for American Studies

Electronic reference

Mirosław Filiciak, "Will You Awaken When Your Netflix No Longer Works? American Films, Television

Productions and Social Transformations in Poland", European journal of American studies [Online], 13-3

2018, Online since 07 January 2019, connection on 08 July 2021. URL: http://

journals.openedition.org/ejas/13568; DOI: https://doi.org/10.4000/ejas.13568

This text was automatically generated on 8 July 2021.

Creative Commons License 


\title{
Will You Awaken When Your Netflix No Longer Works? American Films, Television Productions and Social Transformations in Poland
}

\author{
Mirosław Filiciak
}

1 "Freedom. What do you need freedom for? You've got TV." Thus begins "Po co wolność" ("Freedom? What For?"), a song by Kult, one of the most popular bands in the history of Polish rock music. It comes from their 1989 album titled Kaseta (Cassette), a highly suggestive name in the context of this essay as it refers to the main medium of music distribution used at the time. Like most Kult songs, the lyrics provide a commentary on the social and political situation in Poland, and the above quoted words from the beginning of the song are followed by examples of how the authorities (still communist at the time) bribed the citizens with little comforts. It is not by chance that the TV opens the list here and that the rest of the song, which includes "a gratuitous ration of spirit," there are abundant references to TV shows. As Iwona Kurz, the historian of Polish culture, notes, in the 1970s and 80s popular culture images of Polish TV were unambiguous. It was represented as a tool for escapism and mass hallucinations (Kurz 390). Yet, these images related mostly to the propagandistic role of the national TV, filled with programs produced by Poland and the Comecon countries. The audiences' reception of what came from behind the Iron Curtain was entirely different.

2 In this essay, I will discuss the historical transformations of the status of access to TV and cinema content in Poland from the 1980s till today. However, I will not focus on particular shows but will, instead, bring them under the common denominator of American productions. My main interest will lie in the models of access to this content. Sonia Livingstone and Ranjana Das' research will constitute my major point of reference here. As they argue, if, according to the Anglo-American tradition of cultural studies, media is both texts and objects, then audiences likewise have a double nature: 
they read texts but they also re-produce social relations (Livingstone and Das 105-106). I will explore here the status nature of such reproduction and the dynamics of its transformations. The local aspect of my analysis will, of course, be of great importance here, especially in the context of Polish audiences' encounter with American content. I will look at how the mythologized West, which was an important point of reference for Poles and was identified with American productions in the realm of popular culture, functioned during and after the political transformations. I will also explore which types of encounter with American audiovisual content have been perceived as productive of prestige.

3

Referring to cinema and TV productions made in USA is important not only because of the role the US has played as a world production center but also in the context of a phenomenon which Alexandr Kiossev describes as self-colonization: an uncritical fascination with the West driven by the fear of one's own peripheral status (Kiossev). This is hegemony without domination, a situation which is the opposite, or perhaps a mirror reflection, of the relation of the countries of Central and Eastern Europe with the "East" personified by the Soviet Union. The Soviet Union had successfully imposed its domination on Poland for over four decades; accordingly, in the social imagination it retained the status of an aggressor. The West enjoyed a different status: Poles yielded to it voluntarily, even with enthusiasm in terms of culture and politics. We can see this in the overwhelming majority of elites' uncritical attitude towards to the shock therapy (a US import, to a large extent) given to our country after 1989. The elites have remained, until today, impervious to any discussion about economic models alternative to neoliberalism.

4 I thus adopt here a cultural studies perspective in which not only content, but also, and even primarily, the ways of accessing it and the social practices linked to it are of crucial importance. Since in this short essay I will analyze transformations beginning in the 1980s and lasting until today, interpreting particular films or series would miss the point and would provide only anecdotal evidence for my arguments. Analyzing types of content, and especially the ways of distributing it to viewers, is justified given the fact that access to audiovisual content, not only in Poland, has undergone significant changes over the last three decades, mainly due to technological progress. The arrival of the VCR and satellite TV in the 1980s loosened state control over the circulation of the content but also became a point of reference for the aspirations of the culture of consumption of those times. Beginning with a historical outline, I discuss how the changing technological platforms have continued to express the aspirations and identity of its users despite the political change in Poland and the processes of globalization.

\section{Going to Movies or... the VCR Show?}

During the Polish People's Republic, access to American content was severely restricted. US films, as well as American TV series, reached Poland in meager amounts, often considerably delayed and, obviously, selective. They almost always achieved considerable success, which is at odds with the image of those times cultivated by Polish intelligentsia. As Arkadiusz Lewicki shows, the dominant image of the cinema audiences in the Polish People's Republic who, or so it is often assumed, watched ambitious films and abundantly participated in film societies, finds no confirmation in 
statistics (46). Lewicki also notes that the interest in Polish and European cinema, so often evoked today, can at least partly be treated as caused by lack of access to American productions. In 1964, a year of record attendance, Hollywood films constituted a mere $15 \%$ of the cinema programs in Poland. Afterwards, the percentage was sometimes higher, yet Hollywood productions continued to be meted out, sparingly and selectively, by the communist authorities.

However, it was already by the mid-1980s that the state began to lose control over what Poles were watching. This loss was mostly caused by the boom of the VHS. It was then that the culture of viewership began to develop. American films (often of poor technical quality caused by multiple copying) and access to devices which enhanced the status of their owners were significant elements of this culture. The status in question was not only material. Possessing a VCR, or at least having access to it, called for financial resources which in the Polish People's Republic were inextricably linked with resourcefulness, something valued immensely in Polish culture. In a radically centralized economy, both preferential access to commodities and opportunities to increase one's revenue required a network of contacts and an ability to move skillfully within it. Though such a comparison may be overdrawn, we can note here certain analogies to how the VCRs functioned in other countries, semi-peripheral or peripheral from the perspective of the economic center. I am referring here to Immanuel Wallerstein's world systems theory which segments the world on the basis of division of labor. Core countries use higher-skill production, while periphery countries focus on labor-intense production and extraction of raw materials. Semi-periphery countries have double characteristics and mediate between centers and peripheries (Wallerstein). The division of labor and access to products connected with it affect local cultures and peoples' cultural practices built around media. We could mention here the Salomon Islands, discussed by Jean-Marc Philibert and Christine Jourdan (61). Seen as very prestigious electronic devices, the VCRs were not always used there in the way intended by the manufacturers because, for example, the users did not have enough competence to operate them. What is more, when the device broke down, it was frequently left unrepaired because of limited access to service centers. Yet for the owners, using the devices did not need to be more important than the prestige derived from possessing them. The situation in Poland seemed to be strikingly similar until the fall of the communist system.

7 In the first half of the 1980s, most VCRs which were available in Poland arrived through what can be called "private import," or, to be more precise, smuggling. Later, they were sold, for dollars, by the state-owned chain stores Pewex and Baltona. It is estimated that already by the mid-1980s, there were over half a million VCRs in Poland, and counting (Gaweł 1). This figure is quite high given that at the beginning of the decade the VCR cost an equivalent of an average salary of five years. Afterwards, it cost an equivalent of the salary of several months. In order to obtain a possession of the VCR, resourcefulness was also needed. It allowed people to increase the official salary and buy the VCR at a price absurdly high from our viewpoint. What was also needed was the ability to mobilize the reservoirs of knowledge necessary to obtain the films or to connect the devices themselves to incompatible color systems or cables, which frequently required appropriate expertise. For this reason, home VCR screenings of American movies-often organized for neighbors and friends-were in fact spectacles of the status of the hosts with the VCR functioning as a medium of prestige. These 
aspirations corresponded with the images shown in the films because in the social imagination of the Polish People's Republic the US was a country of widespread affluence based on the entrepreneurial spirit of its citizens. The owners of the VCR saw themselves as doubly avant-garde: people who in comparison to the rest of the population had an easier access to American pop culture but also as people who, through their actions and abilities to make money effectively, personified the Western spirit of resourcefulness and thus were closer not simply to American films, but to the American way of life. This, by the way, also corresponds to the narrative which was dominant in the Polish People's Republic, even in the official media, a narrative about Poland's backwardness and its constant chase after the West. The VCRs allowed people to feel that the distance separating them from the West got somewhat diminished.

Films available on VHS cassettes covered a wide range, also because in the absence of official distribution, the copies of films (disseminated mostly at the markets) belonged to different types of circulation which were kept separate in their countries of origin. From the perspective of the viewers who came into their possession, mostly through the purchase or exchange of pirate copies, these differences were often imperceptible. In the same place, often side by side on the same cassette, one could get not only action films, but also a B horror movie and arthouse cinema. Porn movies, which became an essential component of most home collections, acquired a unique status. This brief deregulation of the cultural taboo resulted from the fact that watching porn movies was treated not only as a manifestation of access to a new means of circulation, but also as circumvention of moral censorship which was identified with up-to-datedness. This censorship was not only a result of the policies of the government, but also of the values propagated by the Catholic church which supported the opposition. The confusion of the types of circulation also occurred in the case of Polish productions. In the interviews I and Patryk Wasiak held as part of our research on the social life of the VCR in Poland, we heard, among others, a story told by a VCR fan who as a teenager, by the end of the 1980s, watched Ryszard Bugajski's Przestuchanie (Interrogation, 1982). It may just as well be the most famous Polish film banned from distribution (the film was made in 1982 but it premiered only on December 13, 1989). An iconic film among those which leveled accusations against the communist regime, it tells a story of a woman tortured by the Office of Public Security in Stalinist Poland. When watched by a professional technical school student, it was mostly seen as a Polish equivalent to the subgenre of the cinema of exploitation ("women in prison"), popular in VCR circulation. Even if this case is an anecdotic one (since it is impossible to determine the range of similar interpretations today), it proves that at least in some part of the society video fans derived pleasure from an erotic tension generated by the tormenting of the female protagonist rather than from the evidence it provided for the cruelty of the authorities.

9 The raptures over the freedom inscribed into this channel of distribution began to wear off rather fast by the end of the 1980s, which can clearly be seen in how the cultural elites related to the VCR cassettes. Initially, they reached for the VCR mostly because they saw it as a medium challenging and unsettling the state monopoly on the distribution of information and cultural texts. Yet it was also seen as a medium which allowed people to watch films such as the already mentioned Interrogation, and the most recent American cinema. The VCR screenings were organized in the salons of the opposition intelligentsia. It soon turned out, however, that although the new technology provided access to content inaccessible in official circulation, it would also 
come to transform the entire media and culture ecosystem. In the cinema and on TV, distribution was centralized-the program was chosen by party officials, but sometimes also by the cultural elite cooperating with media and cultural institutions. In the case of the VCR, it proved to be entirely different. The discouragement is perfectly captured in Agnieszka Osiecka's famous text "Wydeo" (the misspelling reflecting the mispronunciation of the word video), which was published in Polityka, a Polish weekly, in 1989. The VCR, the eponymous "wydeo," is represented as a symbol of the birth of the new middle class, wanting in taste and obsessively watching action cinema (the article obviously cites Rambo starring Sylvester Stallone).

It is worth noting, however, that such processes were local in character. Somewhat belatedly, they also followed the phenomena one could encounter in the West. In his new introduction to the influential 1979 book Popular Culture and High Culture: An Analysis and Evaluation of Taste, Herbert Gans mentions the media, including the VCRs, as a factor of cultural divergence in the USA. Writing about "cultural wars" and the diversification of tastes, Gans reminds us that they were, in fact, an element of class struggle in which the VCR and computers played a significant role supporting the development of new cultural niches (3-25). The change of the cinema program, but especially the change of the institutions regulating film distribution, became part of the symbolic struggles between former elites and the new middle class whose economic and political significance continued to grow. It was thus in the interest of the middle class to enhance the cultural competences which had hitherto remained outside the canon. Of course, bringing the US and Poland into a comparative perspective calls for some clarification. At the turn of the 1970 s and 80 s, the American white middle-class still enjoyed the delusion of growth. In Poland, the consumerist boom and the development of the management caste in the 1970s, vividly depicted, for instance, in the TV series Czterdziestolatek (dir. Jerzy Gruza, 1975), were brutally stopped already at the beginning of the 1980s when the martial law was introduced. The reduction of the standard of living and the awareness that the authorities were capable of brutal acts provided the background to the VCR revolution in Eastern Europe. This does not change the fact that there were internal tensions between the existing elites (the intelligentsia managed to maintain such status in the times of the Polish People's Republic) and the new groups of economic advancement that aspired to claim the position of the intelligentsia.

11 In Poland, the tension over the extension of cultural capital (an extension taking place under the pressure from groups gaining in economic strength but having limited high culture competence) was mostly related to the rhetorical strategies of intelligentsia attempting to defend its position (this process is still visible in the public life; see Zarycki). At the moment, radical neoliberal economy began to gain ground, this group, which during the Polish People's Republic had retained a strong position despite censorship, now feared degradation at the hands of the new middle class. The middle class had been burgeoning since the 1970s, but was relatively less educated and held a different set of values. This paradox touched upon the ambivalent relationship with the West which the Polish intelligentsia saw as an oasis of civil freedom antithetical to the Soviet Union, on the one hand, but, in the context of the 1980s/1990s economic transformations, also as a symbol of consumerism detrimental to high culture. 


\section{Pirate Modernisation in a Digital Mode}

12 The modernization of Polish culture, described above, was of a "dirty" character which brings to mind the transformations of Indian cities Ravi Sundaram has called "pirate modernity" (see Sundaram). The term describes the modernization of public space in which new media played a key role but which, despite this technological support, had an improvised, pirate character. Simultaneously, this pirate character could be detached from the rhetoric of protest against the dominant system because what was at stake was not only a break-up with the past, but also consumption within available means. Above all, it was based on local innovations which combined new technological solutions with grassroots activities focusing on the reduction of access costs. This involved, in particular, pirate copying and the development of a system for the circulation of copies. However, the liberation from under the influence of the Soviet Union, which also manifested itself in the realm of popular culture, fueled (as was the case in postcolonial countries) new forms of entanglements. On the one hand, it meant a growing proximity to the countries of the economic and cultural center, a proximity mediated by technology; on the other, a simultaneous participation in their culture by means of pirate solutions. While exploring the Nigerian VCR market, Brian Larkin describes this phenomenon as the "colonial sublime," that is, processes in which viewers who aspire to enter fully the realm of Western pop culture at the same time use the equipment imported from the West and maintain a conviction about the superiority of its implied users (Larkin 35-44). In the case of the VCR pirate market, this superiority was everywhere to be seen given the low quality of recordings, the poor quality of dubbing superimposed on the original sound track, sometimes subtitles in foreign languages or logotypes of Western TV stations one could see on the recordings. They made it clear to the viewers that they were not the intended audience of the content and that this content reached them only by way of an enforced recycling. They showed that the Polish audience-despite the substantial costs they believed they had borne-remained incompatible with the Western circulation of content; just like the VCRs which coded colors in the PAL system were incompatible with Eastern European TVs which operated in the SECAM system.

13 It is clear, in the light of the argument presented in this essay, that the situation was radically changed neither by the fall of communism (which did not, after all, entail a leveling out of economic differences) nor by the technological transformations. Each new technology, though holding a promise of egalitarianism, continued to reproduce the dependence between the center and the semi-peripheries even if it enabled a local economy of prestige, itself enabling the production of differences within Polish society. However, this was not obvious at the beginning of the transformations because in some ways the situation had diametrically changed after 1989. State censorship was lifted, and new distribution channels appeared. The copyright law was implemented in 1994. What now signified the social prestige was the legal access to various kinds of audiovisual content, including rentals of DVDs and paid satellite channels. This, to a large extent, corresponded to the situation in other countries as discussed, among others, by Barbara Klinger (Beyond the Multiplex). Home audiovisual sets, as well as the collections of DVDs, constituted a specific manifestation of cinephilia which was based on access to both economic capital (the equipment) and cultural capital (collecting films). What also signified prestige was access to TV channels of the premium segment 
(Canal + or HBO) available only on subscription. Yet there were also pirate alternatives even to these premium media-the informal circulation of films also included the TV and pirate decoders were widely available on the market. At any rate, only recently did the development of terrestrial digital television diminish the interest in satellite and cable TV, both very popular in Poland. In 2012, seven million Poles used paid satellite platforms, while almost five million had cable TV subscriptions (Szewczyk). Despite access to free channels, a substantial part of the population used satellite or cable TV, which makes it difficult to see them as signifiers of prestige. Yet like in the era of the $\mathrm{VCR}$, change occurred at the moment a new solution cropped up. It again linked, unambiguously, access to a channel to access to symbolic capital, not necessarily invoking, in any direct way, the economic status of the viewers.

This change was obviously brought about by the internet. At the turn of the century it was being popularized in Poland and was used by the statistically younger, welleducated and urban part of the population (Batorski). What is more, the diversity of its uses and the proficiency of its users who aimed to render their every-day life more efficient were visibly linked with the amount of the cultural capital the users enjoyed (Filiciak, Mazurek and Growiec). Due to the development of high-speed connections and new formats of film coding which enabled transmission through the internet, from the beginning of the twenty-first century on, new platforms developed facilitating an exchange of files in the peer-to-peer architecture. Their use-a unique return of the piracy of the VCR era in a novel form detached from any contact with intermediarieswas at first primarily available to educated youth, and, on account of the quality of connections, restricted mostly to big cities. It was also linked with cultural competences: knowing English or having the ability to find subtitles with their translation. And although piracy is often blamed by Polish distributors for impoverishing the official offer, it was at that time that the next generation understood that the films downloaded outside the official distribution channels were more interesting and ambitious than those available in the cinema and on TV.

The scale of the informal digital internet distribution gradually increased encompassing around one third of the population (Filiciak, Hofmokl and Tarkowski). Forms of sharing unauthorized content underwent change, making access more egalitarian. Cda.pl, a web hosting and media service established in 2003, a phenomenon unique on a world scale, is a symbol of that change. It allows its users to share films on the internet and access them through streaming. As is easy to guess, most of the offer violates copyrights even if the service only provides a platform where films are shared by its users. The service has over eight million users, which makes it the most popular video sharing platform in Poland after YouTube. This is an example showing that the current change of the ecosystem of access to pirate audiovisual content is not only about the forms of content exchange (the easy to use streaming rather than file exchange), but also about the creation of professional services. These services are treading the path paved earlier by the Polish video game industry. The founders of the world-renowned developing studios such as CD Projekt or Techland began their careers as sellers of pirate games (see Filiciak). This is why Cda.pl is getting ready to enter the stock market and trying to sign legitimate contracts with distributors. What is more, beside the proceeds from commercials, it also reaps profits from premium subscription.

Pirate distribution can also help, however, to promote new types of content as was the case with informal screenings of Japanese animations at American campuses. This 
gradually paved the way for the popularity of anime in the US (Jenkins 156-161). Similar examples can be found in Poland where American TV series of the new generation gained popularity online first and only later did the official distribution take advantage of it. Again, the already familiar situation developed: an entire gamut of content which blurred the dividing line between various formats came to be ennobled through the distribution channel.

\section{TV and Intergenerational Tensions}

Contemporary quality TV, in its TV series version, often linked with The Sopranos by HBO, constitutes the culmination of the transformations in the American TV industry of the 1980s. It is above all a culmination of the development of satellite TV, the deregulation of the cable TV market and the establishment of an influential position by networks such as HBO, which generate profit not from commercials but from subscriptions. In a nutshell: the progressive segmentation of the viewers gave rise to more productions tailored to smaller audiences. Addressing their productions to the relatively affluent and well-educated portions of the society (not only American), cable TVs began to experiment with shows which did not shy away from talking about ambiguous situations and controversial characters, and eagerly played with conventions often breaking moral taboos along the way. The latter was possible as they were not subject to legal regulations binding for American open access broadcasters. The development of new technologies which enabled timeshifting also played a certain role here. In Poland, a groundbreaking show which initiated the fashion for TV series downloaded from the internet was Prison Break by the Fox Broadcasting Company. This could be seen as another example of the significant role of the medium of distribution. Prison Break was not a series comparable in any degree to the productions from the Fox premium segment. After the internet success, the series was bought by the open-access TV channel Polsat on which it enjoyed immense popularity.

Again, we can note a similar pattern here: the sense of prestige is produced by a particular access channel and is then gradually dispelled when access is made egalitarian and when the content is dispersed through other forms of distribution, such as television platforms. And thus again, we find in Poland a pirate version of an American phenomenon. Jane Feuer, who explores the phenomenon of new generation TV series, draws on the category of not $T V$, a category used in the marketing strategies of HBO and stemming from the slogan: It's not TV. It's HBO (154-155). According to Feuer, this slogan delineates real points of reference for new generation TV series (she refers, for example, to Six Feet Under, which was promoted as arthouse TV, closer to theatre plays or literature than traditional series) but also for their inspirations. She argues, ironically, that such explorations are immanent to television genres. This shift towards the realm of art or high culture is significant, though. Television, even on the level of the texts it creates and distributes, no longer fits within what has traditionally been associated with TV. But, for marketing reasons, it willingly wears and sports this novel garb. It boasts of not being TV thus creating a new segment of viewers who treat the traditional TV with contempt or as a form of guilty pleasure. However, in Poland, not $T V$ content ended up in a medium different from premium channels: pirate internet channels. It thus paved the way for the emergence of other access platforms, with Netflix at the forefront. 
19 Netflix, an indubitable icon of the transformations of TV, has been available in Polish only since September 2016. Yet access to Netflix remains elite. During the first months, when popularity was driven by the one-month free trial, the service reached the level of a million subscribers. At the moment, the number reaches 760 thousand (Ula). Again, the subscribers are mostly young people in big cities (see PS). It seems that what is essential for the provider to attract a wider audience is not economy (it is common knowledge that many users, loyal to the Polish tradition of resourcefulness, share their accounts) but cultural competence which manifests itself in taste. As Pierre Bourdieu would put it, "taste classifies, and it classifies the classifier" (6). It is mostly young and educated Poles aspiring to join the global middle class who seem to be the Netflix audience. Raised in the EU, they sever themselves from the generation of their parents when it comes to taste and ways of using new content. According to statistics, the generation of their parents is less inclined to choose Netflix. For this reason-even if this decision may seem risky-I treat access to this platform as another sign of changes linked with the specific status of Netflix. This platform is simultaneously the producer and distributor of the audiovisual content-it functions as both the TV and a digital medium which is based on recommendation algorithms and allows viewers to use the content in a manner closer to computer data bases than traditional forms of access to audiovisual content. As such, it fits my discussion of the various modes of access, in which not only the content itself but also the mode of access (i.e. the mediation of a given device or service) are of great importance.

From this perspective, Netflix is seen as a database which Lev Manovich describes as a cultural form, making possible a (re)presentation and (re)configuration of culture in ways not possible before the era of the computer (218-243). Yet as Jose van Dijck, among others, has shown, the logic of a database reconfigurable by means of social media permeates nowadays the online sociality, or even sociality as such (Culture of Connectivity). Such platformed sociality generates concerns among the elderly who see such ways of building relationships with others as inauthentic (moving boundaries between private, public and corporate) or self-interested (connectivity can be seen as a resource). What they also find worrisome is the new logic of creating such social connectivity which the platformed sociality enables. Without entering into the discussion on the validity or invalidity of such opinions, I see in this logic of managing one's own social networks a certain break from the logic underlying older types of media. They allowed for a smaller circle of friends that was more difficult to reconfigure or connect to sub-circles. We can compare these two types of logic to the difference between the TV and social media. The former provided content which could be discussed by friends who met on other occasions; the latter enabled a swift and convenient switch of groups with which an individual comes to interact. Seen in a broader perspective, the possibilities offered by social media have political consequences. They enable the construction of thematic and also hobby-oriented social networks allowing the users to switch from one to another. On the intergenerational level this leads to identity tensions. It also, in a sense, levels various aspects of an individual's life by bringing them all under one common denominator: from the choice of TV programs to the matter of one's world view.

This intergenerational tension was brought to light in an interesting way thanks to Dorota Wellman, a well-known journalist who for almost a decade has been one of the most recognizable people of the TVN station. Within the Polish TV ecosystem of the last 
two decades, TVN is a station identified with urban audiences, mostly voting for the current opposition. Wellman has recently written an open letter to young people blaming them, in a way similar to the lyrics of the song which open this essay, for giving up on political resistance in favor of sitting in front of the screen. The title of the text in which she accused the young of passivity in the face of the threat of new authoritarianism read: "Does it really make no difference to you in what country you live? Will you awaken when your Netflix no longer works?"

This symbolic reference to Netflix reveals another division linked to the ways of using TV. This time, however, it is not about the simple difference between a more or a less prestigious medium. Wellman is a journalist who represents a broadcaster seen as a mouthpiece of the full-belly section of the generation of transformations who are a beneficiary of the systemic changes in Poland. It would be difficult to defend the thesis that she could be envious of those young people in their 20 s or 30 s who are building their professional careers in a new, highly precarious environment. Watching productions such as House of Cards indicates, instead, a consciousness of living in a world of weakened traditions and disappearing points of reference, both at the level of access to TV and of more broadly understood patterns of behavior typical of a given social group. It constitutes an element of an identity performance eluding simple classifications but simultaneously corresponding to the conditions in which young people have to function. The labor market which offers "flexible forms of employment" does not help them to function according to the traditional TV program format. The Netflix content, convenient due to easy access but still sophisticated in terms of cultural competence, has become a method of managing everyday life but also one's own image by means of the media. As such, this content resembles the processes of simultaneously identifying with many groups which have little in common. It also signifies a unique alliance with the content provider who demands payment for one's adaptation to those conditions. Once more, the Polish intelligentsia feels threatened by media changes because once more they have received, in the same package offering an attractive content, the tools to reconfigure social networks and manifest their transformed shape.

\section{BIBLIOGRAPHY}

Batorski, Dominik. "Wykluczenie cyfrowe w Polsce“. Studia BAS 3(19) (2009): 223-249. Print.

Bourdieu, Pierre. Distinction: A Social Critique of the Judgment of Taste. Trans. Richard Nice. Cambridge, MA: Harvard University Press, 1984. Print.

Feuer, Jane. "HBO and the Concept of Quality TV“. In: Quality TV: contemporary American television and beyond. Ed. J. McCabe and K. Akass. London: IB Tauris, 2007. 145-158. Print.

Filiciak, Mirosław, Justyna Hofmokl and Alek Tarkowski. The Circulations of Culture: Mashup. A Research Report. Warszawa: Centrum Cyfrowe, 2012.

https://obiegikultury.centrumcyfrowe.pl/mashup/?lang=en. Accessed November 12, 2018. 
Filiciak, Mirosław, Paweł Mazurek and Katarzyna Growiec. Korzystanie z mediów a podziały społeczne. Warszawa: Centrum Cyfrowe, 2013.

https://centrumcyfrowe.pl/projekty/korzystanie-z-mediow-a-podzialy-spoleczne/. Accessed November 12, 2018.

Filiciak, Mirosław. “Playing Capitalism. The Polish People’s Republic, Constructing Memory, and Video Games." Widok 11 (2015).

http://pismowidok.org/index.php/one/article/view/314/677. Accessed November 12, 2018.

Gans, Herbert. Popular Culture and High Culture: An Analysis and Evaluation of Taste. New York: Basic Books, 1999. Print.

Gaweł, Piotr. “Pierwsza Runda dla Rocky’ego.” Polityka 11 (12 March 1988). Print.

Jenkins, Henry. Convergence Culture. New York: New York University Press, 2008. Print.

Kiossev, Alexandr. “The Self-Colonizing Metaphor”. Atlas of Transformation. 2011.

http://monumenttotransformation.org/atlas-of-transformation/html/s/self-colonization/theself-colonizing-metaphor-alexander-kiossev.html.

Accessed November 12, 2018.

Klinger, Babara. Beyond the Multiplex: Cinema, New Technologies, and the Home. Berkley: University of California Press, 2006. Print.

Kurz, Iwona. “Telewizja: szyby niebieskie od telewizorów.” Obyczaje polskie. Wiek XX w krótkich hasłach. Ed. M. Szpakowska. Warszawa: WAB, 2008. Print.

Larkin, Brian. Signal and Noise: Media, Infrastructre, and Urban Culture in Nigeria. Durham: Duke University Press, 2008. Print.

Lewicki, Arkadiusz. "Ilu widzów oglĄdało ‘bergmany’? Dystrybucja i widownia filmowa w Polsce wczoraj i dziś-mity i fakty.” Wokół zagadnień dystrybucji filmowej. Ed. M. Adamczak and K. Klejsa. Łódź: PWSFTviT, 2015. 33-60. Print.

Livingstone, Sonia, and Ranjana Das. "The End of Audiences?: Theoretical Echoes of Reception Amid the Uncertainties of Use." A Companion to New Media Dynamics. Ed. J. Hartley, J. Burgess, A. Bruns. Oxford: Wiley-Blackwell, 2013. 104-121. Print.

Manovich, Lev. The Language of New Media. Cambridge, MA: MIT Press, 2001. Print.

Osiecka, Agnieszka. "Wydeo". Polityka 22 (3 June 1989). Print.

Philibert, Jean-Marc, and Jourdan, Christine. "Perishable Goods: Modes of Consumption in the Pacific Islands." Cross-Cultural Consumption, Global Markets, Local Realities. Ed. David Howes. London: Routledge, 2004: 55-76. Print.

PS. "Netflix z niestabilnĄ odwiedzalnością w Polsce, maksymalnie 386 tys. użytkowników miesiĘcznie." 2017.

https://www.wirtualnemedia.pl/artykul/netflix-w-polsce-liczba-uzytkownikow-miesiecznie. Accessed November 12, 2018.

Sundaram, Ravi. Pirate Modernity. London: Routledge, 2010. Print.

Szewczyk, Łukasz. “GUS: 4,8 mln abonentów TV kablowej i 6,9 mln użytkowników TV satelitarnej”. Media2. 2013. 
https://media2.pl/media/106695-GUS-48-mln-abonentow-TV-kablowej-i-69-mln-uzytkownikowTV-satelitarnej.html. Accessed November 12, 2018.

Ula. "Netflix rośnie w siłŁ̨. Coraz wiĘcej abonentów także w Polsce”. Rzeczpospolita. 2018.

https://www.rp.pl/Media-i-internet/310189973-Netflix-rosnie-w-sile-Coraz-wiecej-abonentowtakze-w-Polsce.html. Accessed November 12, 2018.

van Dijck, Jose. The Culture of Connectivity: A Critical History of Social Media. New York: Oxford University Press, 2013. Print.

Wallerstein, Immanuel. "Semi-Peripheral Countries and the Contemporary World Crisis". Theory and Society 3.4 (Winter 1976): 461-483. Print.

Zarycki, Tomasz. "The Power of the Intelligentsia: The Rywin Affair and the Challenge of Applying the Concept of Cultural Capital to Analyze Poland's Elites." Theory and Society 38(6) (2009): 613-648. Print.

\section{ABSTRACTS}

This article is devoted to the historical changes of the status of access to American TV and cinema content in Poland. Using the framework of cultural studies, media are treated here both as texts and objects. The analysis of case studies from the VHS era as well as of contemporary online streaming services connects the way people access video content with the production of social prestige, and shows how changing styles of video consumption mark social transformations in contemporary Poland.

\section{INDEX}

Keywords: American films, American television, VHS, cultural studies, media, distribution, social status

\section{AUTHOR}

\section{MIROSŁAW FILICIAK}

Mirosław Filiciak, presently the Dean of the Faculty of Arts and Social Sciences at the SWPS University in Warsaw, is a cultural and media studies scholar. His research interests include digital networked media changes, informal distribution of information and media archaeology. He was principal investigator on numerous research projects, including "Youth and Media" and "The Circulations of Culture." 